\title{
Paclitaxel induces apoptosis in AIDS-related Kaposi's sarcoma cells
}

\author{
JIE CAI, ${ }^{1}$ TONG ZHENG,${ }^{1}$ RIZWAN MASOOD,${ }^{2}$ D. LYNNE SMITH, ${ }^{1}$ DAVID R. HINTON, ${ }^{2}$ \\ CARYN NAE KIM, ${ }^{3}$ GUOFU FANG ${ }^{3}$ KAPIL BHALLA ${ }^{3}$ \& PARKASH S. GILL ${ }^{1}$
}

\author{
${ }^{1}$ Departments of Medicine and ${ }^{2}$ Pathology, University of Southern California, Kenneth Norris Comprehensive Cancer Center \\ and Research Institute, Los Angeles, CA, USA, ${ }^{3}$ Division of Clinical and Translational Research, Sylvester Comprehensive \\ Cancer Center, University of Miami, FL, USA
}

\begin{abstract}
Paclitaxel is a microtubule stabilizing drug that causes dividing cells to arrest and then undergo apoptosis. It also has antiangiogenic activity because it alters cytoskeletal structure, affecting migration and invasion. Paclitaxel is an effective treatment for AIDS-related Kaposi's sarcoma (KS). KS is a tumor in which there is marked proliferation of endothelial cells in addition to the tumor cells, which themselves share many markers with activated (proliferating) endothelial cells. We sought to determine the mechanism by which paclitaxel exerts its anti-KS tumor effects. In vitro, KS cells are very sensitive to paclitaxel, with half-maximal growth inhibition observed at $0.8 \mathrm{nM}$. Inhibition of migration of KS cells was also observed at nanomolar concentrations of the drug. Paclitaxel induced cell cycle arrest with an accumulation of cells in sub-G1. This was accompanied in vitro by various events typical of apoptosis: phosphorylation of two anti-apoptotic proteins Bcl-2 and $\mathrm{Bcl}-\mathrm{x}_{\mathrm{L}}$, release of cytochrome $\mathrm{c}$ into the cytoplasm, cleavage and activation of caspase-3. In vitro results were borne out by studies of KS tumor xenografts in nude mice. Paclitaxel $(10 \mathrm{mg} / \mathrm{kg})$ inhibited tumor growth by $75 \%$ over 21 days. Histological examination of the tumors revealed a decrease in proliferative index, a decrease in the number of mitotic figures and an increase in apoptotic cells compared to tumors from untreated mice.
\end{abstract}

Key words: AIDS, apoptosis, Kaposi's sarcoma, paclitaxel, Taxol

\section{Introduction}

Kaposi's sarcoma is the most common tumor in patients with human immunodeficiency virus type 1 (HIV-1) infection. ${ }^{1}$ Clinically, $\mathrm{KS}$ manifests most commonly on the skin and mucus membranes as multicentric lesions, with subsequent spread to visceral organs. ${ }^{1} \mathrm{KS}$-related mortality is secondary to visceral organ disease. There has been debate as to whether KS is a true neoplasm, or merely represents a local hyperproliferation reaction in response to inflammatory cytokines and growth factors. With the results of two groups that show clonality in $\mathrm{KS}$ lesions this debate appears to be resolving in favor of the neoplastic nature of the disease. $^{2,3}$

$\mathrm{KSHV} / \mathrm{HHV}-8$, a recently identified herpes virus, is a strong candidate for the etiologic agent for all forms of KS, whether classical, AIDS-associated or endemic. Molecular epidemiology studies have shown that nearly all KS tumors contain viral genome, suggesting an etiological link to this virus. ${ }^{4}$ Seroepidemiology studies show that KS patients have a very high prevalence of $\mathrm{KSHV} / \mathrm{HHV} 8$ antibodies (90\%) which is elevated above the non-KS population (5-20\% in the USA). Further, in countries with HIV but no documented KS, KSHV seroprevalence is very low $(2-4 \%) .^{5}$

Pathologically, the tumor exhibits an extensive vascular network of slit-like spaces, which differ from normal vessels in that they lack basement membranes and the presence of abnormal spindle-shaped endothelial cells (tumor cells) lining these vessels. The pathological examination of the tumors suggests that the origin of KS tumor cells is endothelial, a hypothesis that is supported by phenotypic studies. Markers shared with endothelial cells include lectin binding sites for Ulex europeaus agglutinin-1 (UEA-1), CD34, EN-4, PAL-E, ${ }^{6}$ ELAM-1, ${ }^{7}$ VE-cadherin ${ }^{8}$ and the recently identified endothelial cell specific tyrosine kinase receptors, VEGFR-1 (Flt-1), VEGFR-2 (Flk-1/KDR), VEGFR-3 (Flt-4), Tie-1 and Tie-2. ${ }^{9-11}$ In addition to expressing many endothelial proteins, KS cell growth is strongly dependent on the angiogenic factors vascular endothelial growth factor (VEGF), ${ }^{9}$ basic fibroblast growth factor (bFGF), ${ }^{12}$ 
and to a lesser extent, interleukin-8 (R.M., T.Z., P.S.G., unpublished data).

Paclitaxel has shown potent anti-tumor activity in several tumor types. ${ }^{13-16}$ Paclitaxel increases tubulin polymerization, which results in cell-cycle arrest due to inhibition of mitotic spindle formation. ${ }^{17}$ Prolonged cell-cycle arrest has been associated with phosphorylation of the Bcl-2 protein. ${ }^{18}$ The Bcl-2 family of proteins plays a central role in programmed cell death or apoptosis, in which anti-apoptotic members such as Bcl-2 and $\mathrm{Bcl}-\mathrm{x}_{\mathrm{L}}$ balance the activities of the pro-apoptotic members such as Bax and Bad. ${ }^{19,20}$ Heterodimerization of Bcl-2 with Bax is critical in preventing Bax-mediated apoptosis. ${ }^{21,22} \mathrm{Bcl}-2$ and Bax have additional opposing actions in apoptosis since Bcl-2 prevents the release of cytochrome $\mathrm{c}$ from mitochondria ${ }^{23}$ while Bax promotes cytochrome c release. ${ }^{24}$ Cytochrome c release results in binding to Apaf-1 followed by activation of caspase 9 and effector caspases $^{25}$ that are active in the effector phase of apoptosis. $^{26}$

In addition to inducing apoptosis, paclitaxel may also exert its anti-tumor activity through inhibition of angiogenesis. Paclitaxel alters cytoskeletal structures and inhibits endothelial cell migration in vitro and in vivo. ${ }^{27}$ Paclitaxel has also been shown to inhibit angiogenesis in the chicken chorio-allantoic membrane (CAM) assay $^{28}$ and bFGF induced angiogenesis in the mouse corneal neovascularization model. ${ }^{29}$

Since $\mathrm{KS}$ is a highly vascular tumor we first sought to determine the sensitivity of KS to paclitaxel in vitro and in vivo. We found that very low (nanomole) concentrations of paclitaxel induced tumor cell death. We show that the mechanism of anti-tumor action of paclitaxel in $\mathrm{KS}$ is accompanied by phosphorylation of $\mathrm{Bcl}-2$, release of cytochrome $\mathrm{c}$ into the cytoplasm and activation of caspase-3.

\section{Materials and methods}

\section{Cell proliferation assays}

The immortalized KS cell lines KS Y-1 ${ }^{30}$ and KS-SLK ${ }^{31}$ were grown in wells coated with $1.5 \%$ gelatin in KS medium consisting of RPMI-1640 (Life Technologies, Gaithersburg, MD), $100 \mathrm{U} / \mathrm{ml}$ penicillin, $100 \mu \mathrm{g} / \mathrm{ml}$ streptomycin, $2 \mathrm{mM}$ glutamine, $1 \%$ essential and non-essential amino acids, $10 \%$ fetal bovine serum (FBS: Life Technologies), and $1 \%$ Nutridoma-HU (Boehringer Mannheim, Indianapolis, IN). HUVEC (Clonetics, San Diego, CA) were grown in medium containing epidermal growth factor and according to the instructions of the supplier. Cells were plated at a density of 10000 cells/well in 48-well gelatin coated plates on day 0. Similarly, AoSM (Clonetics, San Diego) cells were seeded in 48 well plates at the same density in their growth media on day 0 . On days 1 and 3 cells were treated with various concentration of paclitaxel. On day 5, cells were treated with 3-[4,5-dimethylthiazol-2-yl]- 2,5-diphenyltetrazolium bromide (MTT) at a final concentration of $0.5 \mathrm{mg} / \mathrm{ml}$. Cells were incubated for 2 hours, medium was aspirated and the cells were dissolved in acidic isopropanol (90\% isopropanol, $0.5 \%$ SDS and $40 \mathrm{mM} \mathrm{HCl}$ ). Developed color was read in an ELISA reader using the isopropanol as blank (Molecular Devices, CA).

\section{Cell migration assays}

Cell migration assays were performed in transwells with $8 \mu \mathrm{m}$ pores (Costar, Cambridge, MA). Briefly, wells were coated with fibronectin $(25 \mu \mathrm{g} / \mathrm{ml})$ overnight, and the endothelial cells or KS cells were plated in $100 \mu \mathrm{l}$ of DMEM/0.4\% FCS in the upper chamber. $500 \mu$ of DMEM/0.4\% FCS was added to the lower chamber and incubated at $37^{\circ} \mathrm{C}$ for 1 hour. Paclitaxel (0.01-100 nM) was added to the upper chamber, and chemotaxis agents (VEGF $20 \mathrm{ng} / \mathrm{ml}$ ) to the lower chamber. The plates were incubated for 16 hours at $37^{\circ} \mathrm{C}$ and the cells crossing the fibronectin-plated membrane were quantitated after wiping the cells off the upper chamber with a cotton swab. The cells across the membrane were stained with Diff-Quik stain set according to the manufacturer's instruction (Dade Diagnostics Inc., Aguada, PR). The cells were counted at $320 \mathrm{X}$ in four randomly selected fields. The experiments were done in duplicate and repeated at least three times.

\section{Apoptosis assays}

Internuclear fragmentation of genomic DNA was assessed after incubation of the cells with paclitaxel. DNA from $1 \mu 10^{6}$ cells was extracted and sizefractionated by agarose gel electrophoresis as described previously. ${ }^{32} \mathrm{KS}$ cells were also analyzed by flow cytometry for cell cycle and apoptosis after incubation with paclitaxel. The cell pellets were fixed in $70 \%$ alcohol, washed and the nuclei were stained with propidium iodide solution for analysis as described previously. ${ }^{33}$ The samples were read on a Coulter Elite flow cytometer using Elite software program 4.0 for two-color detection. The percentage of cells in the apoptotic sub-G1, G1, S, and G2-M phase were calculated using Multicycle software (Phoenix Flow Systems, San Diego, CA).

\section{Protein analysis}

The levels of Bcl- $x_{\mathrm{L}}, \mathrm{Bcl}-2$ and Bax and their phosphorylation status, levels of cytosolic cytochrome c, activation of caspase-3, proteolysis of poly (ADPribose) polymerase (PARP), and cleavage product of DNA fragment factor (DFF) in control cells and in response to paclitaxel treatment were also examined in KS cells. These assays were performed by Western blot using specific antibodies conjugated to horseradish peroxidase. ${ }^{34-38}$ 
In vivo tumor growth

In vivo studies were performed in $\mathrm{BALB} / \mathrm{c} \mathrm{NU}^{+} / \mathrm{nu}^{+}$ athymic mice by implanting KS Y-1 cells (10 million cells each) subcutaneously. Mice were treated with paclitaxel $(5$ and $10 \mathrm{mg} / \mathrm{kg}$ ) or an equal amount of vehicle control intraperitoneally on days $1,5,9,14$ and 21 . Tumor sizes were measured on days 14 and 21. Tumor volume was calculated with the formula $V=0.52 \mathrm{LW}^{2}$. Six mice were treated in each group. Mice were handled throughout in compliance with IACUC regulations.

\section{Histological analysis of in vivo tumors}

In other experiments, tumors were allowed to grow for 14 days and treated with 5,10 , or $20 \mathrm{mg} / \mathrm{kg}$ of paclitaxel. Tumors were excised 24 hours later, fixed in $4 \%$ paraformaldehyde, imbedded in paraffin, sectioned and analyzed for the mitotic index, and apoptosis in situ. Immunoperoxidase staining for the proliferation-related antigen, $\mathrm{Ki}-67$ was performed using MIB-1 monoclonal antibody (Immunotech, Marseilles, France). After incubation with the primary antibody, staining was completed using the ABC immunoperoxidase method on an automated stainer (Techmate 1000, BioTek, Santa Barbara, CA). Diaminobenzidine (DAB) was used as the peroxidase substrate. TUNEL staining for apoptosis was performed using the ApopTag in situ apoptosis detection kit (Oncor, Gaithersburg, $\mathrm{MD}$ ) according to the protocol supplied by the manufacturer. In this method cut DNA is localized in situ by end-labeling, using terminal deoxyribonucleotidyl transferase (TdT) and an digoxigenin-deoxyuridine 5-triphosphate substrate. The bound digoxigenin is detected immunohistochemically using antidigoxigenin-peroxidase antibodies. Peroxidase was visualized using aminoethylcarbizole (AEC) as the chromogen (AEC kit, Zymed Lab Inc., San Francisco, CA). Negative controls included substitution of water for TdT. For each tumor, cell density was determined on H\&E sections by counting the number of nuclei in 5 representative $1 \mathrm{~mm}^{2}$ sections. The number of morphologically identifiable mitotic figures was counted in these same regions of the H\&E stained sections. The labeling index for MIB-1 and TUNEL positive cells was performed by determining the percentage of labeled nuclei in 5 representative $1 \mathrm{~mm}^{2}$ sections from each tumor.

\section{Results}

\section{Paclitaxel inhibits $K S$ cell proliferation and migration}

We examined the effects of paclitaxel on KS cell proliferation in vitro. The $50 \%$ inhibitory concentration $\left(\mathrm{IC}_{50}\right.$ ) for paclitaxel was $0.8 \mathrm{nM}$, and $90 \%$ inhibition was observed at $10 \mathrm{nM}$ (Fig. 1a). In contrast, endothelial cells (HUVEC) and aortic smooth muscle cells (AoSM), were less sensitive, with $\mathrm{IC}_{50}$ of $6.6 \mathrm{nM}$ and $4.7 \mathrm{nM}$, respectively. We also investigated the effects of paclitaxel on KS cell migration in response to bFGF. Paclitaxel inhibited KS cell migration with an $\mathrm{IC}_{50}$ of $1.1 \mathrm{nM}$ (Fig. 1b). Inhibition of migration (16 hours) occurred earlier than inhibition of proliferation ( 5 days). For all concentrations of paclitaxel except the highest tested $(100 \mathrm{nM})$, we do not observe cell death at 16 hours.

\section{Paclitaxel induces apoptosis in KS cells}

Exposure of KS cells to paclitaxel produced a dosedependent increase in internucleosomal DNA fragmentation (Fig. 2a). This was associated with an increase in the fraction of sub-G1 cells with DNA content below that of the interphase resting cells $(<2 \mathrm{~N})$ (Fig. 2b). Annexin V is translocated to the cell

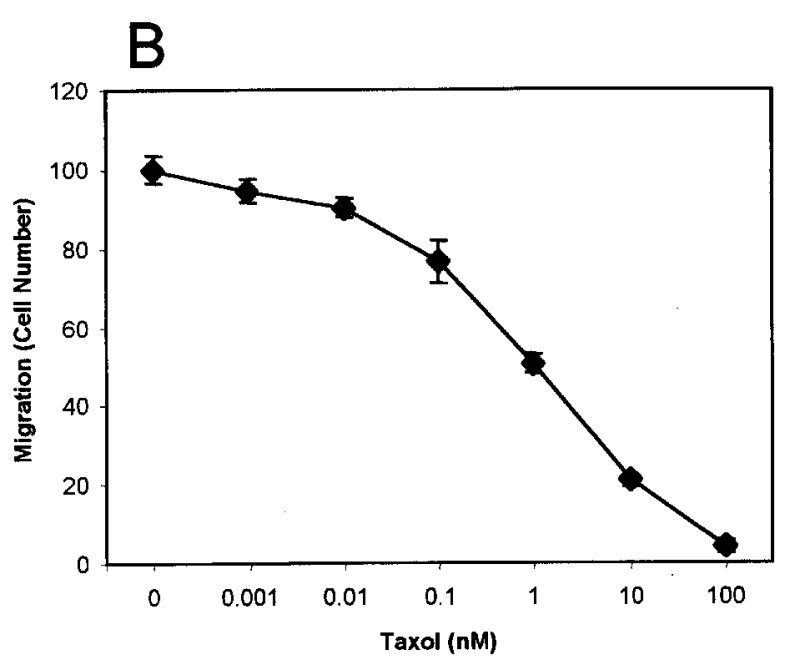

Figure 1. Taxol inhibits proliferation and migration of KS cells. (a) KS Y-1, HUVEC and AoSM cells were plated at equal density $\left(1 \mu 10^{3}\right.$ cells/well) and treated with Taxol on days 1 and 3 at the concentrations shown. Cells were counted on day 5 . (b) migration assays were done in double chamber wells separated by a fibronectin-coated membrane. Chemotaxis was induced by addition VEGF $(20 \mathrm{ng} / \mathrm{ml})$ to the lower chamber. Cells $\left(5 \mu 10^{4} / \mathrm{ml}\right)$ were placed in the upper chamber in the presence and absence of paclitaxel at the concentration shown. Migration of KS Y-1 cells across the membrane was quantitated after overnight incubation. The results represent the mean \pm standard error of assays performed in quadruplicate. 
A

B

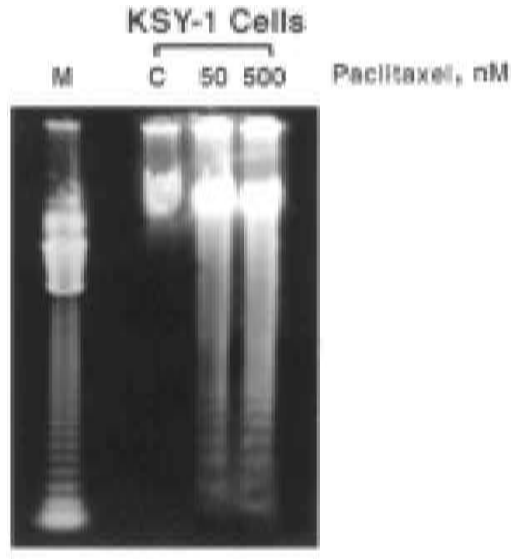

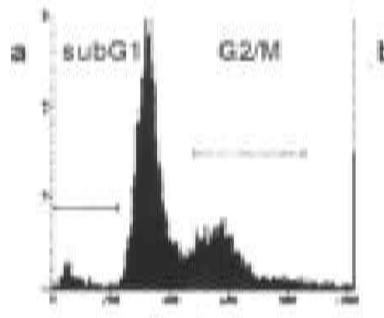

contiroll

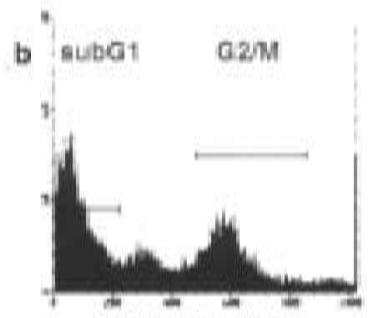

Pacilaxel, 50 nM

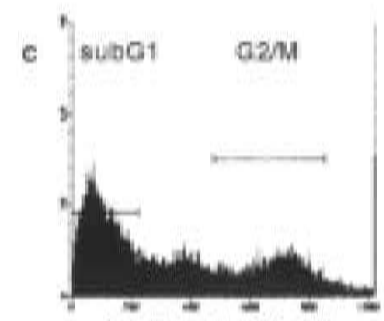

Pachliagel, $500 \mathrm{~min}$

Figure 2. Taxol induces internucleosomal DNA fragmentation and increases the fraction of sub-G1 cells with $<2 N$ DNA content. (a) Following exposure of KSY-1 cells to 50 or $500 \mathrm{nM}$ Taxol for 24 hours, the genomic DNA was extracted, purified and subjected to agarose gel electrophoresis. (b) Flow cytometric determination of DNA content and cell cycle status of KS Y-1 cells treated with Taxol for 24 hours compared with untreated cells (control). The areas of the plots that represent cells in sub-G1 and G2/M phase of the cell cycle are indicated. There is a dose-dependent increase in sub-G1 cells with $<2 N$ DNA content.

surface during apoptosis and is used as a marker of apoptotic cells. We stained KS cells exposed to 0.1 to $100 \mathrm{nM}$ paclitaxel with Annexin V to determine the fraction of apoptotic cells in vitro. It can be seen in Fig. 3 that $25 \%$ of cells were apoptotic following 24 hour exposure to $100 \mathrm{nM}$ paclitaxel. At $500 \mathrm{nM}$ paclitaxel, the highest concentration used in other experiments reported in this study, $48 \%$ of cells exhibited morphologic features of apoptosis.

Caspase-3 is activated upon paclitaxel treatment of KS cells

We further investigated the mechanism of KS cell death in response to paclitaxel. One of the pivotal proteases active in apoptosis is caspase-3, which degrades several protein substrates including poly (ADP-ribose) polymerase (PARP). ${ }^{37,38}$ Twenty-four

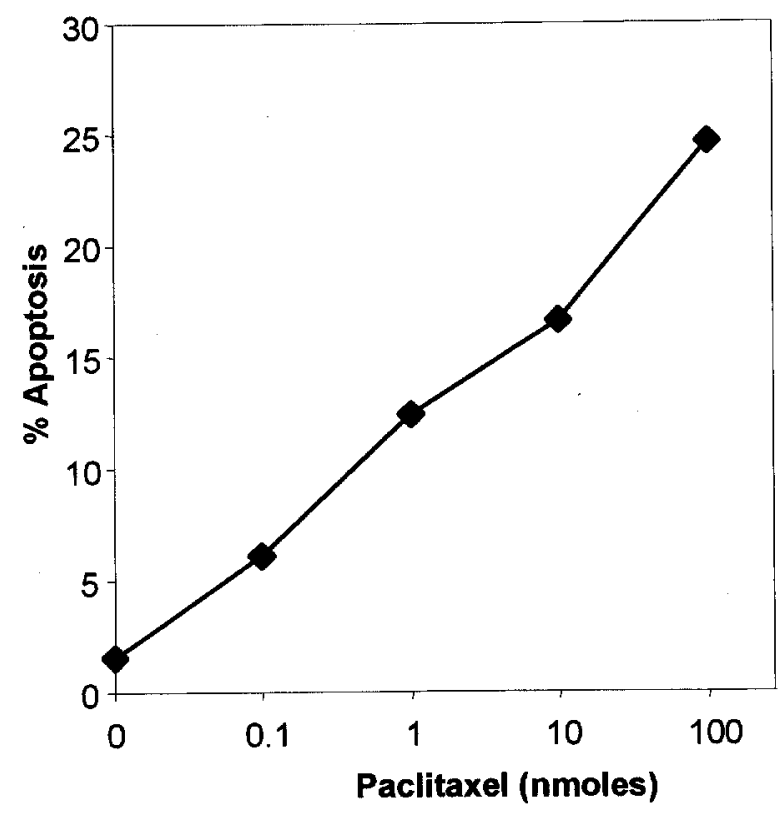

Figure 3. Taxol treatment leads to apoptosis of KS cells. Following exposure of the Kaposi's sarcoma cell line, KS Y-1, to paclitaxel $(0.1,1,10$, and $100 \mathrm{nmol})$ for 24 hours, the cells were trypsinized and stained for annexin V. Cells displaying annexin

$V$ on the cell surface were quantitated by flow cytometry.

hour treatment of KS cells with paclitaxel resulted in a dose-dependent cleavage of full-length procaspase-3 (Fig. 4a). This was associated with the degradation of caspase-3 substrate PARP into its $85 \mathrm{kD}$ (Fig. 4a) and $31 \mathrm{kD}$ (not shown) fragments.

Paclitaxel induces phosphorylation of Bcl-2 and Bcl-x $x_{L}$ in KS cells

The mechanism of paclitaxel-induced apoptosis involves modulation of regulatory proteins such as Bcl-2, Bcl- $x_{L}$, and Bax. Figure $4 b$ demonstrates that exposure of $\mathrm{KS}$ cells to paclitaxel for 24 hours results in the appearance of slower-mobility species characteristic of the phosphorylated forms of Bcl-2 and $\mathrm{Bcl}-\mathrm{x}_{\mathrm{L}}$. Under the same treatment Bax levels were unchanged. A time course of $\mathrm{KS}$ cell exposure to $500 \mathrm{nM}$ paclitaxel showed that phosphorylation of Bcl-2 and $\mathrm{Bcl}-\mathrm{x}_{\mathrm{L}}$ had reached a peak by 5 hours, whereas caspase- 3 activation measured by cleavage of PARP was not appreciable until 12 hours (Fig. 4c).

Cytochrome c is released by paclitaxel treatment in KS cells

Release of cytochrome c from the mitochondria into the cytosol may precede apoptosis. We determined whether this occurred in KS cells in response to paclitaxel. Paclitaxel, but not etoposide, resulted in cytochrome c release into the cytoplasm after 24 hour treatment (Fig. 5). This release of cytochrome c was associated with the induction of downstream apoptotic events in the same cells. Two substrates of caspase-3, PARP and DFF, were cleaved into smaller forms (Fig. 5). 


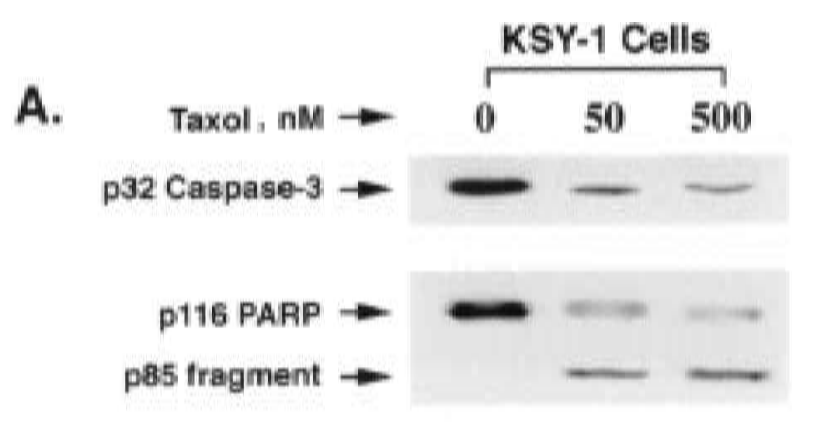

B.
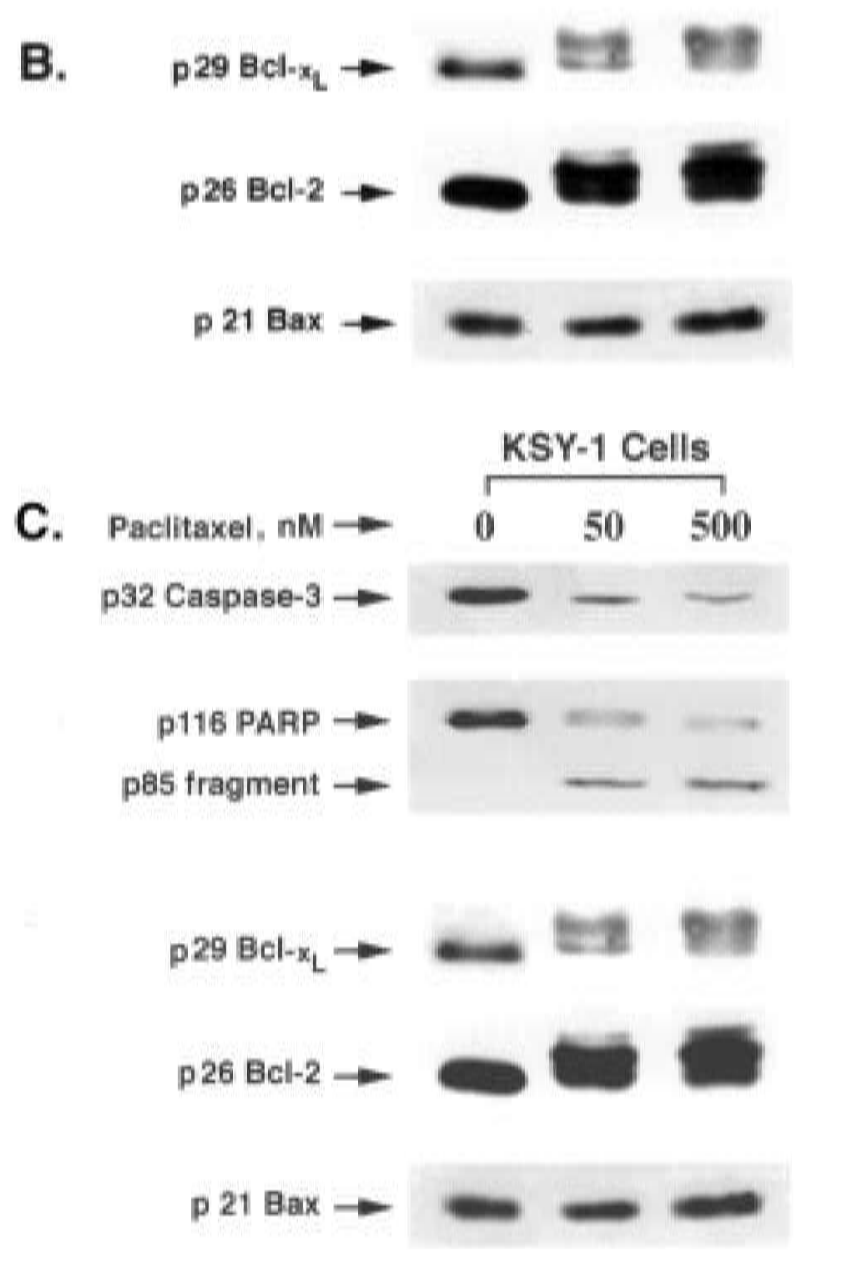

Figure 4. Taxol induces Bcl-2 phosphorylation and the molecular cascade of apoptosis in KS Y-1 cells. KS Y-1 cells were exposed to the indicated concentration of Taxol for 24 hours. Western blot analysis of several apoptotic markers. (a) Decrease in procaspase-3 (p32 caspase-3; by cleavage; see text) and degradation of caspase-3 substrate $116 \mathrm{kD}$ PARP into its $85 \mathrm{kD}$ and $31 \mathrm{kD}$ (not shown) fragments. (b) Treatment with Taxol produced a dose-dependent increase in slower mobility phosphorylated $\mathrm{Bcl}-2$ and $\mathrm{Bcl}-x_{L}$ bands, whereas $B$ ax levels remain unaltered. (c) Western analyses of the levels of $p 29 \mathrm{Bcl}-x_{L}, p 26 \mathrm{Bcl}-2$, full-length caspase-3, as well as the analysis of the caspase-3 activity by determining the in vitro cleavage of ${ }^{35} S$-labeled PARP by cellular protein extracts from untreated and paclitaxel (500 nM) treated cells for 5, 8, 12, and 24 hours. Exposure to $500 n M$ paclitaxel for $\geq 5$ hours resulted in a time-dependent increase in the phosphorylation of Bcl-2 and Bcl-x $x_{L}$. A decline in the $p 32$ caspase-3 levels and PARP cleavage activity occurred after exposure to paclitaxel for at least 12 hours.

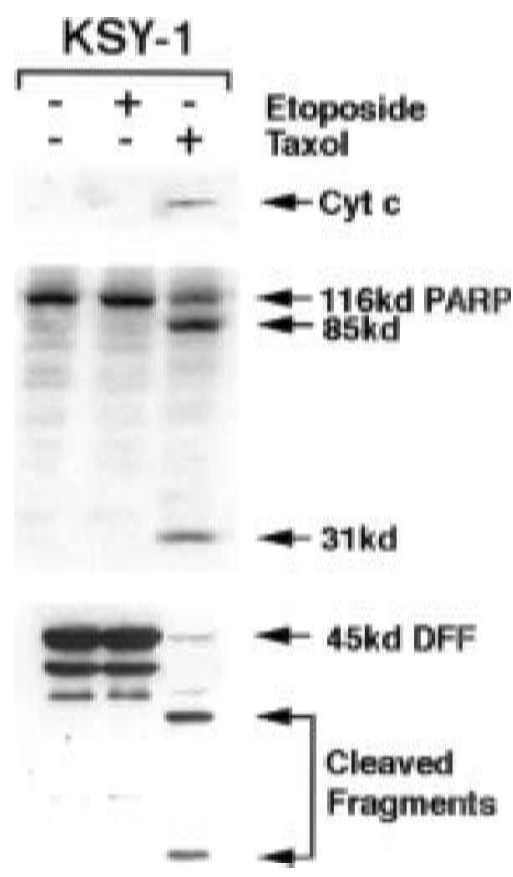

Figure 5. Taxol induces apoptosis in KS Y-1 cells by release of cytochrome c.Western analysis of cytosolic cytochrome $c$ (cyt c) levels and the $45 \mathrm{kD}$ subunit of DNA fragmentation factor (DFF). ${ }^{35}$ S-labeled in vitro translated Poly (ADP-ribose) polymerase (PARP) or its 85 and $31 \mathrm{kD}$ cleavage products were analyzed from the $S-100$ fraction from the untreated, etoposidetreated ( $50 \mu \mathrm{mol}$ for 4 hours), or paclitaxel-treated ( $50 \mu \mathrm{mol}$ for 24 hours) KS Y-1 cells. Treatment with paclitaxel but not etoposide induced cytosolic accumulation of cytochrome $c$ as well as PARP and DFF-45 cleavage activity.

In vivo effects of paclitaxel on KS tumors

The effects of paclitaxel on KS tumors in vivo were next determined using tumor xenografts in nude mice. Tumor response was observed in mice treated with a paclitaxel dose of $10 \mathrm{mg} / \mathrm{kg}$ (Fig. 6a). In other experiments, tumors were excised 24 hours after a single dose of either 5 or $10 \mathrm{mg} / \mathrm{kg}$ and studied for apoptosis in situ, and for their effect on the mitotic index. A dose-dependent increase in the cells undergoing apoptosis (Fig. 6b) and a decrease in the mitotic index were observed (Fig. 6c). Comparison of the histology of the control and paclitaxel treated tumors revealed frequent mitotic figures in the control tumors (Fig. 6d) which were reduced upon paclitaxel treatment (Fig. 6e). Immunoperoxidase staining for the proliferation marker Ki-67 showed a significant reduction in paclitaxel treated compared to control tumor (Figs 6g, f). TUNEL staining was performed to quantify the in vivo apoptosis. When compared to control (Fig. 6h) paclitaxel treated tumor (Fig. 6i) showed a marked increase in the number of TUNELpositive cells. When adjusted for cell density, the increase in apoptosis was even more prominent.

\section{Discussion}

Paclitaxel has proven effective in the treatment of a variety of cancers ${ }^{13-15}$ including Phase II trials in Kaposi's sarcoma. ${ }^{16,39}$ Because of its highly vascular 

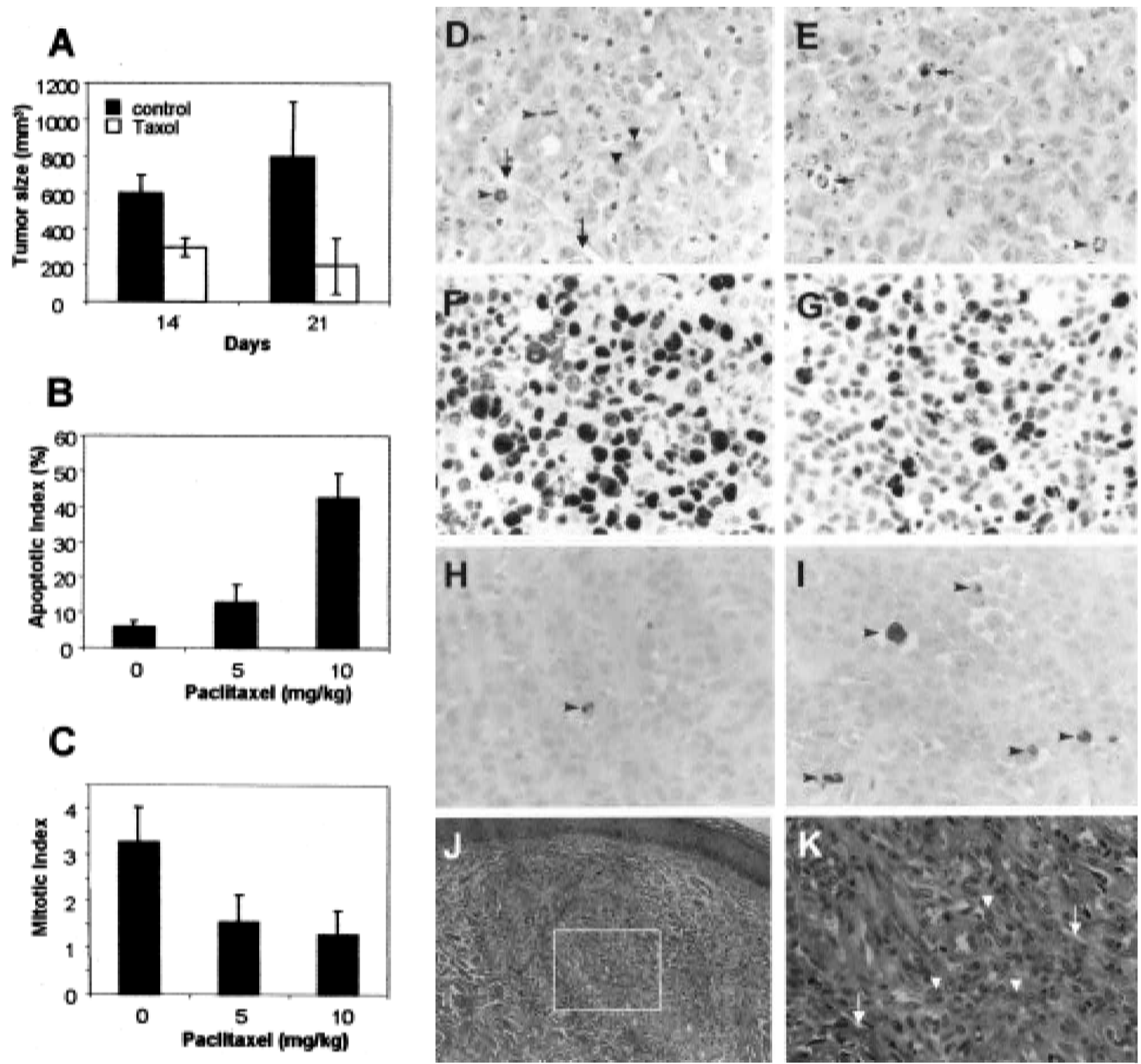

Figure 6. Activity of paclitaxel on Kaposi's sarcoma tumor growth in mice. (a) Mice were treated either with paclitaxel or the control (6 mice per group) intraperitoneally $(20 \mathrm{mg} / \mathrm{kg}$ ) on days 1, 5, 9, 14 and 21 . Tumors were measured on days 14 and 21. The results represent the mean \pm standard error of tumor size. In other experiments, immunodeficient mice were injected with 10 million cells per mouse subcutaneously. Mice were treated with a single dose of paclitaxel at 5 or 10 mg intraperitoneally and the tumors were excised after 24 hours and examined for (b) apoptosis in situ and (c) mitotic index. Histology of taxol-treated tumors. HEE stained sections of control tumors (d) showed a cellular malignant tumor with frequent mitotic figures (horizontal arrow heads). (e) Taxol-treated tumors showed fewer mitotic figures (horizontal arrow heads) and scattered apoptotic bodies (horizontal arrows). (f) Immunoperoxidase staining for the proliferation related antigen Ki-67 using MIB-1 revealed a high labeling index in control tumors. ( $g$ ) In taxol-treated tumors, the MIB-1 labeling index was significantly lower. ( $h$ ) TUNEL staining for apoptotic cells revealed rare apoptotic cells (arrow heads) in control tumors. (i) Apoptotic cells were significantly more frequent in taxol treated cells (arrow heads). An HEE stained section of a typical KS lesion in an AIDS-KS patient is shown ( $j$ ). The area that is magnified in $(k)$ is indicated by the white rectangle. ( $k$ ) High power view of KS biopsy for comparison to KS Y-1 tumor xenograft in mice shown in panels D-I. Both the KS Y-1 xenograft (d) and KS biopsy ( $k$ ) show similar tumor cells (vertical arrowheads in both panels) and the occurrence of slit-like spaces typical of KS lesions (vertical arrows in both panels). 
nature we hypothesized that KS would be especially sensitive to paclitaxel, since both the apoptotic and anti-angiogenic properties of the drug would be in action against this tumor. We therefore set out to examine the response of $\mathrm{KS}$ cells in vitro and in vivo to paclitaxel.

KS cells were very sensitive to the cytotoxic effects of paclitaxel in vitro. The concentration of halfmaximal growth inhibition $(0.8 \mathrm{nM})$ was an order of magnitude lower than reported for several other tumor cell types. ${ }^{40-42}$ The cytotoxic activity of paclitaxel in KS cells was due to apoptosis, and these effects could be seen at a dose as low as $0.1 \mathrm{nM}$ in vitro. Two events indicative of apoptosis, characteristic DNA banding resulting from internucleosomal cleavage, and the appearance of annexin $\mathrm{V}$ on the outer surface of the cell membrane were both observed upon paclitaxel treatment of KS cells.

Having established that paclitaxel induces apoptosis in KS cells, we next undertook to examine the behavior of some of the important apoptotic molecules in these cells. We showed that two antiapoptotic proteins, $\mathrm{Bcl}-2$ and $\mathrm{Bcl}-\mathrm{x}_{\mathrm{L}}$, were expressed in KS cells and phosphorylated after 24 hour treatment with paclitaxel. Phosphorylation of Bcl-2 has been regarded as a marker of apoptosis; however, recent results suggest that phosphorylated $\mathrm{Bcl}-2$ is not in itself an apoptotic protein. ${ }^{18,43} \mathrm{Bcl}-2$ phosphorylation occurs in tandem with mitosis as a normal part of the cell cycle and does not necessarily lead to apoptosis. Bcl-2 can be considered a cell cycle checkpoint protein that responds to mitotic spindle defects in analogy to the checkpoint protein $\mathrm{p} 53$ which responds to DNA damage. It is interesting that KS cells also express $\mathrm{Bcl}-\mathrm{x}_{\mathrm{L}}$, which can compensate for Bcl-2 activity. ${ }^{38}$ We noted that the levels of the pro-apoptotic protein Bax did not change in response to paclitaxel treatment. Presumably, the extended phosphorylation of both $\mathrm{Bcl}-2$ and $\mathrm{Bcl}-\mathrm{x}_{\mathrm{L}}$ in this system releases Bax from heterodimers with these molecules to exert its downstream apoptotic effects. Two of these documented effects are release of cytochrome $\mathrm{c}$ into the cytosol and activation of the caspase family of proteases. We demonstrated that cytochrome $\mathrm{c}$ was released at the concentrations that were used in the other in vitro assays. This is in agreement with results that demonstrate that Bcl-2 blocks the release of cytochrome $\mathrm{c}$ from the mitochondria and that Bax enables its release. ${ }^{23,24}$ In turn cytosolic cytochrome c binds Apaf-1, activates caspase 9 and leads to activation of the caspases, including caspase 3 , which are the effectors of apoptosis. ${ }^{25,26} \mathrm{We}$ thus showed activation of caspase 3 by cleavage of its pro form. In addition to showing that caspase-3 itself was cleaved we showed that it was indeed activated. Activation of caspase 3 coincided with the cleavage of caspase 3 substrates, poly (ADP-ribose) polymerase (PARP) and DNA fragmentation factor (DFF). In this KS cell system peak levels of phosphorylation of
Bcl-2 and Bcl- $x_{L}$ preceded peak caspase-3 activity by at least 7 hours. This is in keeping with the current paradigm of apoptosis in which Bcl-2 phosphorylation leads to free Bax, which in turn leads to release of cytochrome $\mathrm{c}$ from the mitochondria, which then initiates the final phase of apoptosis where proteases are released to effect cell death. ${ }^{23-26}$

The in vivo results in KS tumor xenografts in nude mice mirror the in vitro results. There was significant $(75 \%)$ reduction of tumor size in paclitaxel treated mice and histology of the tumors revealed a decrease in proliferation, a decrease in mitosis and extensive apoptosis of tumor cells compared to untreated controls. The major mechanism of paclitaxel antitumor activity in this model appears to be induction of apoptosis in the tumor cells. While we did show that in vitro paclitaxel inhibited KS cell migration, the contribution of anti-angiogenic effects of paclitaxel was not investigated in vivo. However, there is precedent for a multifaceted anti-angiogenic activity of paclitaxel. Not only does paclitaxel inhibit angiogenesis by interfering with migration of endothelial cells, ${ }^{27}$ but also it induces macrophage production of the anti-angiogenic cytokine IL-12. ${ }^{43}$ This last point may be of significance in KS, which is a tumor highly infiltrated with macrophages.

In conclusion, the anti-KS effect of paclitaxel can in large part be attributed to the apoptosis initiating activity of the drug; however, there is a component of anti-angiogenic action since we showed that KS cell migration was inhibited at low concentrations of paclitaxel.

\section{Acknowledgements}

This study was supported in part by a research grant from Bristol-Myers Squibb, Pharmaceutical Research Institute and by the Bridges and Larson Foundation.

\section{References}

1 Gill PS, Hamilton AW, Naidu Y. Epidemic (AIDSrelated) Kaposi's sarcoma: epidemiology, pathogenesis, and treatment. AIDS Updates 1994;7:1-11.

2 Rabkin CS, Janz S, Lash A, Coleman AE, Musaba E, Liotta L, et al. Monocolonal origin of multicentric Kaposi's sarcoma Lesions. $N$ Engl $\mathcal{f} \mathrm{Med}$ 1997;336:988-93.

3 Gill PS, Tsai YC, Rao AP, Spruck CH 3rd, Zheng T, Harrington WA Jr., et al. Evidence for multiclonality in multicentric Kaposi's sarcoma. Proc Natl Acad of Sci USA 1998;95:8257-61.

4 Albini A, Aluigi MG, Benelli R, Berti E, Biberfeld P, Blasig C, et al. Oncogenesis in HIV-infection: KSHV and Kaposi's sarcoma. Int F Oncol 1996;9:5-8.

5 Chatlynne LG, Ablashi DV. Seroepidemiology of Kaposi's sarcoma-associated herpesvirus (KSHV). Semin Cancer Biol 1999;9:175-85.

6 Lunardi-Iskandar Y, Gill PS, Lam VH, Zeman RA, Michaels F, Mann DL, et al. Isolation and characterization of an immortal neoplastic cell line (KS Y-1) from AIDS-associated Kaposi's sarcoma. F Natl Can Inst 1995;87:974-81. 
7 Fiorelli V, Gendelman R, Sirianni MC, Chang HK, Colombini S, Markham PD, et al. $\gamma$-interferon produced by CD8+ T cells infiltrating Kaposi's sarcoma induces spindle cells with angiogenic phenotype and synergy with HIV-1 Tat protein: an immune response to HHV-8 infection? Blood 1998;91:956-67.

8 Fiorelli V, Gendelman R, Samaniego F, Markham PD, Ensoli B. Cytokines from activated T cells induce normal endothelial cells to acquire the phenotypic and functional features of AIDS-Kaposi's sarcoma spindle cells. F Clin Invest 1995;95:1723-34.

9 Masood R, Cai J, Zheng T, Smith DL, NaiduY, Gill PS. Vascular Endothelial Growth Factor/Vascular permeability factor (VEGF/VPF) in as autocrine growth factor for AIDS-KS. Proc Natl Acad Sci USA 1997;94:979-84.

10 WeningerW, Partanen TA, Breiteneder-Geleff S, Mayer C, Kowalski H, Mildner M, Pammer, et al. Expression of vascular endothelial growth factor receptor-3 and podoplanin suggests a lymphatic endothelial cell origin of Kaposi's sarcoma tumor cells. Lab Invest 1999;79:243-51.

11 McGarvey ME, Flore O, Masood R, Arora N, Zheng $\mathrm{T}$, Smith DL, et al. Expression of endothelial cell specific receptor tyrosine kinases, Tie-1 and Tie-2, Flt-1, Flk-1 and Flt 4 in Kaposi's sarcoma cell lines and in primary tumor tissues. Blood 1998;92:538.

12 Ensoli B, Markham P, Kao V, Barillari G, Fiorelli V, Gendelman R, et al. Block of AIDS-Kaposi's sarcoma (KS) cell growth, angiogenesis and lesion formation in nude mice by antisense oligonucleotide targeting basic fibroblast growth factor: a novel strategy for the therapy of KS. F Clin Invest 1994;94:1736-46.

13 Rowinsky EK, Cazenave LA, Donehower RC. Taxol: a novel investigational antimicrotubule agent. $\mathcal{F}$ Natl Cancer Inst 1990;82:1247-59.

14 McGuire WP, Rowinsky EK, Rosenshein NB, Grumbine FC, Ettinger DS, Armstrong DK, et al. Taxol: a unique antineoplastic agent with significant activity in advanced ovarian epithelial neoplasms. Ann Intern Med 1989;111:273-9.

15 Holmes FA, Walters RS, Theriault RL, Forman AD, Newton LK, Raber MN, et al. Phase II trial of taxol, an active drug in metastatic breast cancer. $\mathcal{F}$ Natl Cancer Inst 1991;83:1779-1805.

16 Saville MW, Lietzau J, Pluda JM, Feuerstein I, Odom J, Wilson WH, et al. Treatment of HIV-associated Kaposi's sarcoma with paclitaxel. Lancet 1995;346:26-8.

17 Horwitz SB, Cohen D, Rao S, Ringel I, Shen H-J, Yang C-PH. Taxol: mechanisms of action and resitance. Monographs, $\mathcal{F}$ Natl Cancer Inst 1993;15:55-62.

18 Scatena CD, Stewart ZA, Mays D, Tang LJ, Keefer CJ, Leach SD, et al. Mitotic phosphorylation of Bcl-2 during normal cell cycle progression and taxol induced growth arrest. F Biol Chem 1998;273:30 777-84.

19 Reed JC. Regulation of apoptosis by bcl-2 family proteins and its role in cancer and chemoresistance. Curr Opin Oncol 1995;7:541-6.

20 Kroemer G. The proto-oncogene Bcl-2 and its role in regulating apoptosis. Nature Medicine 1997;3:614-20.

21 Oltvai ZN, Milliman CL, Korsmeyer SJ. Bcl-2 heterodimerizes in vivo with a conserved homolog, Bax, that accelerates programmed cell death. Cell 1993;74:609-19.

22 Gross A, Jockel J, Wei MC, Korsmeyer SJ. Enforced dimerization of BAX results in its translocation, mitochondrial dysfunction and apoptosis. EMBO $\mathfrak{f}$ 1998;17:3878-85.

23 Yang J, Liu X, Bhalla K, Kim CN, Ibrado AM, Cai J, Peng TI, et al. Prevention of apoptosis by Bcl-2: release of cytochrome c from mitochondria blocked. Science 1997;275:1129-32.
24 Jurgensmeier JM, Xie Z, Deveraux Q, Ellerby L, Bredesen D, Reed JC. Bax directly induces release of cytochrome c from isolated mitochondria. Proc Natl Acad Sci USA 1998;95:4997-5002.

25 Li P, Nijhawan D, Budihardjo I, Srinivasula SM, Ahmad M, Alnemri ES, et al. Cytochrome c and dATPdependent formation of Apaf-1/caspase-9 complex initiates an apoptotic protease cascade. Cell 1997;91:479-89.

26 Harvey KJ, Blomquist JF, Ucker DS. Commitment and effector phases of the physiological cell death pathway elucidated with respect to Bcl-2 caspase, and cyclindependent kinase activities. Mol Cell Biol 1998;18:2912-22.

27 Belotti D, Vergani V, Drudis T, Borsotti P, Pitelli MR, Viale G, et al. The microtubule-affecting drug paclitaxel has antiangiogenic activity. Clin Cancer Res 1996;2:1843-9.

28 Burt HM, Jackson JK, Bains SK, Liggins RT, Oktaba AM, Arsenault AL, et al. Controlled delivery of taxol from microspheres composed of a blend of ethylenevinyl acetate copolymer and poly (d,1-lactic acid). Cancer Lett 1995;88:73-9.

29 Klauber N, Parangi S, Flynn E, Hamel E, Damato RJ. Inhibition of angiogenesis and breast cancer in mice by the microtubule inhibitors 2-methoxyestradiol and taxol. Cancer Res 1997;57:81-6.

30 Lunardi-Iskandar Y, Gill P, Lam VH, Zeman RA, Michaels F, Mann DL, et al. Isolation and characterization of an immortal neoplastic cell line (KS Y1) from AIDS-associated Kaposi's sarcoma. F Natl Cancer Inst 1995;87:974-81.

31 Siegal B, Levinton-Kriss S, Schiffer A, Sayar J, Engelberg I, Vonsover A, et al. Kaposi's sarcoma in immunosuppression. Possibly the results of dual viral infection. Cancer 1990;65:492-8.

32 Ray S, Ponnathpur V, Huang Y, Tang C, Mahoney ME, Ibrado AM, et al. 1- $\beta$-D-arabinofuranosylcytosine-, mitoxantrone- and paclitaxel-induced apoptosis in HL-60 cells: improved method for detection of internucleosomal DNA fragmentation. Cancer Chemother Pharmacol 1994;34:365-71.

33 Darzynkiewicz Z, Bruno S, Del Bino G, Gorczyca W, Hotz MA, Lassotta P, et al. Features of apoptotic cells measured by flow cytometry. Cytometry 1992;13:795808.

34 Bhalla K, Ibrado AM, Tourkina E, Tang CQ, Mahoney ME, Huang Y. Taxol induces internucleosomal DNA fragmentation associated with programmed cell death in human myeloid leukemic cell. Leukemia 1993;7:563-8.

35 Ibrado AM, Huang Y, Fang G, Bhalla K. Bcl-x ${ }_{L}$ overexpression inhibits Taxol-induced Yama protease activity and apoptosis. Cell Growth and Differentiation 1996;7:1087-94.

36 Jordan MA, Wendell K, Gardiner S, Derry WB, Copp $\mathrm{H}$, Wilson L. Mitotic block induced in HeLa cells by low concentrations of paclitaxel (Taxol) results in abnormal mitotic exit and apoptotic cell death. Cancer Res 1996;56:816-25.

37 Martin SJ, Green DR. Protease activation during apoptosis: death by a thousand cuts? Cell 1995;82:349-52.

38 Ibrado AM, Liu L, Bhalla $\mathrm{K}$. Bcl- $\mathrm{x}_{\mathrm{L}}$ overexpression inhibits progression of molecular events leading to paclitaxel-induced apoptosis of human AML HL-60 cells. Cancer Res 1997;47:1109-15.

39 Gill PS, Tulpule A, Espina BM, Cabriales S, Bresnahan J, Ilaw M, et al. Paclitaxel is safe and effective in the treatment of AIDS-related Kaposi's sarcoma. I Clin Oncol 1999;17:1876-83.

40 Tortora G, di Isernia G, Sandomenico C, Bianco R, 
Pomatico G, Pepe S, et al. Synergistic inhibition of growth and induction of apoptosis by 8-chloro- cAMP and paclitaxel or cisplatin in human cancer cells Cancer Res 1997;57:5107-11.

41 Roth W, Wagenknecht B, Grimmel G, Dichgans J, Weller M. Taxol-mediated augmentation of CD95 ligandinduced apoptosis of human malignant glioma cells: association with bcl-2 phosphorylation but neither activation of $\mathrm{p} 53$ nor $\mathrm{G}_{2} \mathrm{M}$ cell cycle arrest. $\mathrm{Br} \mathcal{F}$ Cancer 1998;77:404-11.

42 Gagandeep S, Novikoff PM, Ott M, Gupta S. Paclitaxel shows cytotoxic activity in human hepatocellular carcinoma cell lines. Cancer Lett 1999;136:109-18.

43 Mullins DW, Burger CJ, Elgert KD. Paclitaxel enhances macrophage IL-12 production in tumor-bearing hosts through nitric oxide. F Immunol 1999;162:681 1-8. 


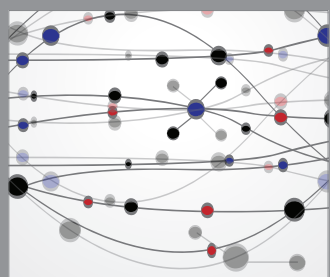

The Scientific World Journal
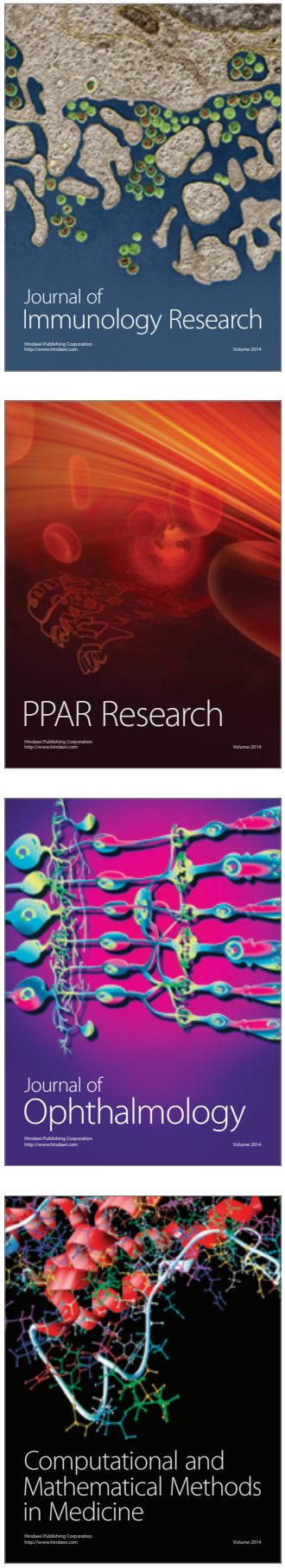

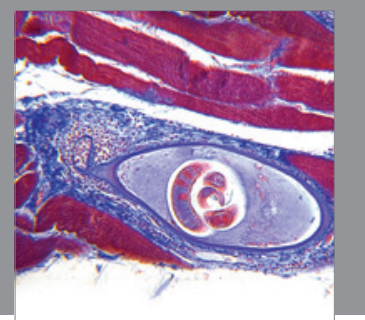

Gastroenterology

Research and Practice
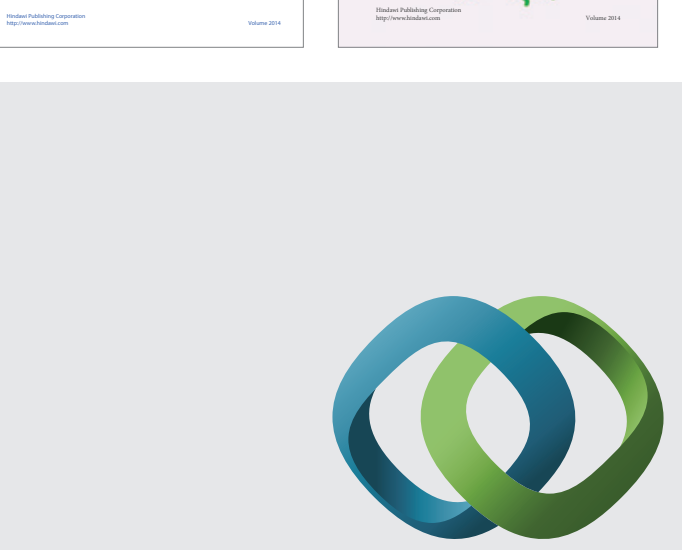

\section{Hindawi}

Submit your manuscripts at

http://www.hindawi.com
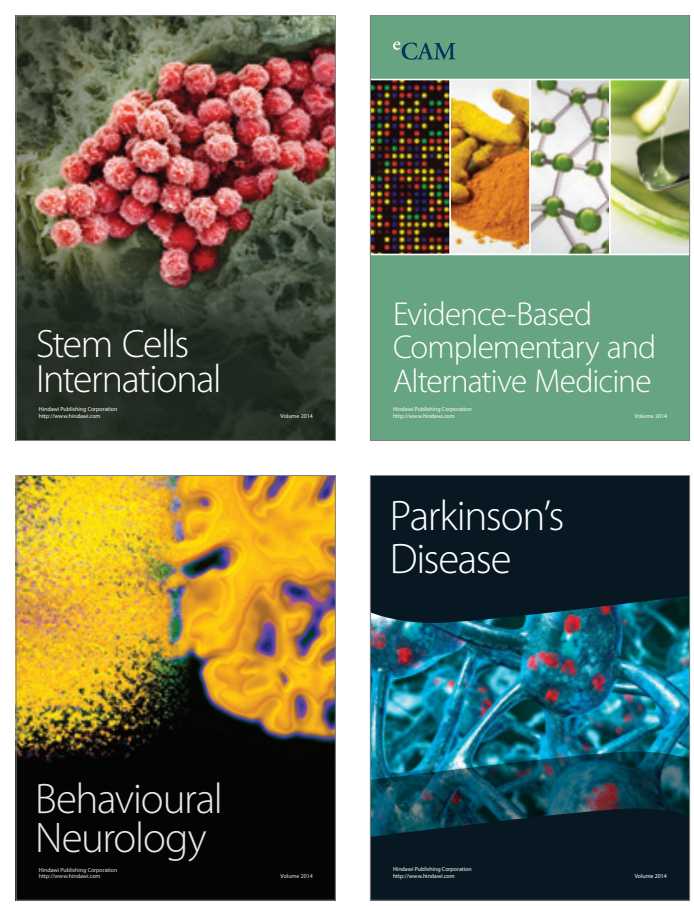

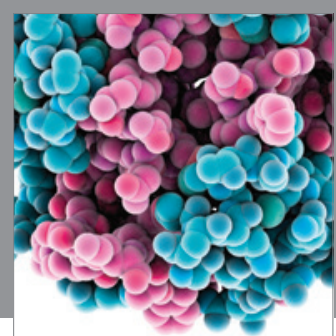

Journal of
Diabetes Research

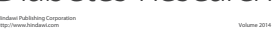

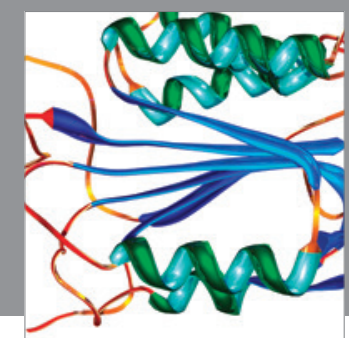

Disease Markers
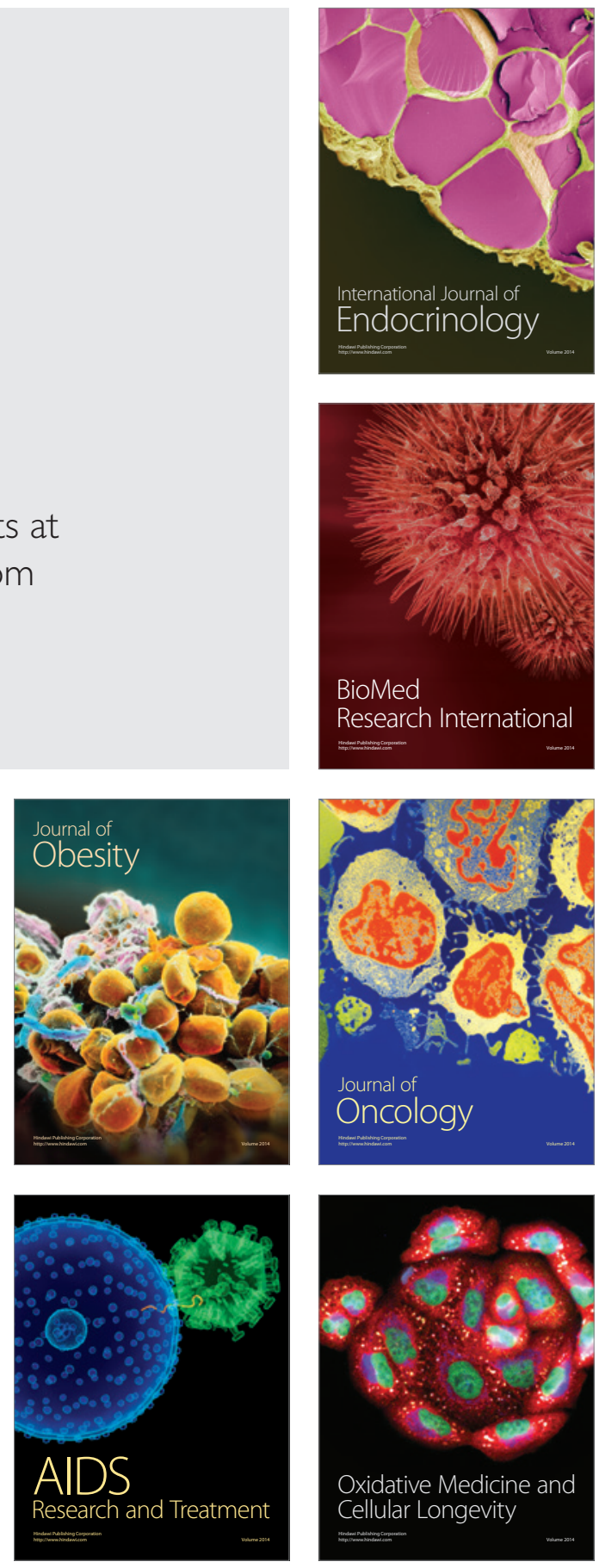